\title{
An ecofriendly root- knot nematode pest management strategy on sugarbeet
}

\section{2- Using some amino and organic acids}

\author{
Maareg, M. F. *; El-Gindi, A. Y. **; Gohar, I. M.A. * and Agami K. M*. \\ * Department of Diseases and Department of Agricultural Practices, Sugar Crops Research Institute, \\ Agricultural Research Center, 12619, Giza, Egypt. \\ ** Department of Zoology, Agricultural Nematology, Faculty of Agriculture, Cairo University, Giza, Egypt.
}

\begin{abstract}
Four amino and organic acids, L-arginine, L-glutamic (as amino acids), ascorbic and salicylic (as organic acids) solution applied as soil drench in three concentration levels to evaluate for nematicidal effects against root-knot nematode, Meloidogyne javanica infecting sugarbeet. Their effects on sugarbeet yield and its components and quality parameters were determined. All of the tested compounds reduced the number of juvenile larvae in soil, immature stages, mature females in root, final nematode population as well as reproduction factor, comparison to the check treatment. These compounds were mostly variable in their effectiveness in reducing nematode infesting or reproduction factor and enhancing plant yield and quality according to compounds type and concentration level used. Then, the percentage of reduction in nematode parameters or/and the increases in crop parameters increased by increasing the concentration level of each tested compound.
\end{abstract}

The ascorbic acid was more effective in reducing nematode fecundity, final nematode population and reproduction factor followed by salicylic acid, L-arginine acid and L-glutamic acid in a descending order. Also, the ascorbic acid component showed the best results in improving leaves, roots, sugar yields and quality parameters of sugarbeet in comparison with the other tested compounds. In comparing between the effects of both ascorbic acid and nematicide, Oxamyl on nematode development and reproduction factors as well as productivity of sugarbeet, the ascorbic acid recorded reduction in juveniles larvae in soil, final population number and reproduction factor with values of $76.3,71.6 \%$ and 2.1 fold, respectively as well as increases in root yield and sugar yield with values of 65.73 and $126.51 \%$, respectively, however, Oxamyl recorded reduction to $73.6,77.3 \%$ and 1.9 fold in juveniles in soil, final population number and reproduction factor, respectively as well as increases to 68.09 and $124.12 \%$ in root and sugar yield, respectively.

The problems associated with nematicides application turned the workers view to focus on new strategies or use new safe components or chemicals for nematode management program. On the other hand, it was obvious from the obtain data, the 
results suggest that using of ascorbic acid (at $4000 \mathrm{ppm}$ rate) could be recommended as instead of chemical nematicide to be a main nematode management approach, whether using as part of an integrated management programs or as sole control component.

Key wards: Amino acids, organic acids, Meloidogyne javanica, root-knot nematode, sugarbeet, Oxamyl.

\section{Introduction}

The genus Meloidogyne, the root-knot nematode, is one of the major biological constrains around the world in most all types of crop plants and causes sever losses in the productivity of sugarbeet in Egypt (Gohar, 2003; Gohar and Maareg, 2005; Maareg and Hassanin, 1992; Maareg et al., 2005). Chemical nematicides, due to their high availability and easy applicability, are generally preferred for their control; however, their excessive and continuous use was reported to have resulted in development of nematicides resistance, caused direct toxicity to predators, pollinators, fish and man, had adverse effects on soil health and environment, and cause poor soil health, fertility, productivity and pesticide residues in products. The problems associated with nematicides application turned the workers view to focus on new approaches that might be adopted to develop non traditional nematicides or use new safe chemicals for nematode management programs. Many research workers studied the effects of some amino and organic acids on plant growth and yield of many crops such as cowpea, soybean, sunflower and tomatoes, as well as their effects on reproduction and development of many nematode species like Helicotylenchus mannus, Heterodera rostochiensis, $H$. schachtii, Meloidogyne spp. and Rotylenchus renoformis (Osman, 1993; Al-Sayed \& Montasser, 1986; Al- Sayed \& Thomason, 1988; Al-Sayed, 1990; 1991; 1992; Hassan, 1999; Klessig et al., 2000; Nandi et al., 2002; Sirohi \& Rohatgi, 2006 and Sirohi et al., 2008).

The aim of this study was to evaluate the nematicidal of some amino and organic acids (as safe chemicals) against $M$. javanica infecting sugarbeet. Also, the effects of all treatments on sugarbeet yield and its components and quality were undertaken.

\section{Material and Methods}

\section{Propagation of Meloidogyne javanica nematode stock culture}

Heavily galled sugarbeet roots var. Helios were collected and carefully washed from the adhering soil particles with tap water. The eggmasses from the egglaying females which were previously identified as $M$. javanica were picked up from the infested roots and singly inoculated into soil planted with 45-days-old tomato seedlings (Lycopersicon esculentum L.) in $1 \mathrm{~m}^{2}$ lysameters filed with stemsterilized sandy loam soil, and watered as needed regularly. The infested 
tomato roots which contained females with their eggmasses were used to renew the stock culture. The pure stock culture in this respect was prepared from infested tomato roots through extraction by the Baermann-pan technique according to Southey (1970).

\section{Inoculation procedures}

In greenhouse experiments, the inoculation was achieved by pouring the second stage juveniles $\left(\mathrm{J}_{2}\right)$ water suspension into four holes $(3-5 \mathrm{~cm})$ depth around the sugarbeet root system which were immediately covered and mixed with soil. Each pot was inoculated with 2000 fresh $\mathrm{J}_{2}$ at the fourth leaf stage seedlings.

\section{Organic and amino acids tested}

Two organic acids (ascorbic and salicylic acids) and two amino acids (Larginine and L-glutamic acids) were tested to their effects against $M$. javanica nematode infecting sugarbeet plants and their effects on plant yield components and quality parameters. These compounds were used as soil drench at the concentration levels of, 1000, 2000 and 4000 ppm (1,2 and $\left.4 \mathrm{~g} \mathrm{liter}^{-1}\right)$ and carried out twice, the first time at the fourth leaf seedling stage and the second one a month later.

Nematicide, Oxamyl 10\% G \{N- N- dimethyl- 2- methylcarbamoyl oxyimino 2- (methylthio) acetamide\} was used as a comparable treatment with amino and organic acids tested. Mixed with soil at concentration levels of 1,2 and $4 \mathrm{~g} \mathrm{pot}^{-1}$ which were applied one time at the fourth leaf seedling stage.

\section{Experimental design}

The experimental soil was calcareous loamy sand with electrical conductivity (E. C) of $1.2 \mathrm{ds} / \mathrm{m}, \mathrm{pH}$ of $8.4, \mathrm{OM}$ of $1.1 \%, \mathrm{CaCo}_{3}$ of $28.3 \%$, soluble cations $\left(\mathrm{Ca}^{++}\right.$ 7.5, $\mathrm{Mg}^{++} 1.7, \mathrm{Na}^{+} 9.6$ and $\left.\mathrm{K}^{+} 4.5, \mathrm{mq}^{-1}\right)$ and soluble anions $\left(\mathrm{CO}^{--} 0.0, \mathrm{HCO}^{-} 8.8\right.$, $\mathrm{SO}^{--} 6.9$ and $\mathrm{Cl}^{-} 8.0 \mathrm{mql}^{-1}$ ) at the $0-30 \mathrm{~cm}$ depth. The soil was air-dried and sieved to pass through a $2 \mathrm{~mm}$. Sieve.

The pot experiment was conducted in the greenhouse under controlled conditions ( $23 \pm 5^{\circ} \mathrm{C}$ and $65 \pm 5 \mathrm{HR}$ ). Seeds of sugarbeet var., Helios were sown in $40 \mathrm{~cm}$ diameter clay pots. Each pot was filed with about $7 \mathrm{~kg}$ of the sterilized experimental soil in October. After germination and at fourth leaf stage, seedlings were thinned to one vigorous plant pot ${ }^{-1}$ one week later, plants were inoculated with freshly 2000 hatched juveniles $\left(\mathrm{J}_{2}\right)$ of root-knot nematode, Meloidogyne javanica. Several treatments were applied to control the $M$. javanica population as shown in Table (1).

Each treatment level was replicated eight times. The experiment included 16 pots (8 pots inoculated with nematode only and 8 pots free of nematode or any treatment) as control, 48 pots of amino acids, 48 pots of organic acids and 24 pots 
of nematicide, oxamyl. All pots were arranged in a randomized pattern on a bench in a greenhouse. Pots were watered daily with tap water. The experiment lasted six months.

At the end of experimental period, the soil of each pot was well irrigated before removing the plant. Roots were washed in a gentle flow tap water. Fresh weights of leaves and roots were recorded (as growth parameters). However, the quality parameters in sugarbeet roots included sucrose percentage determined according to Le-Docte (1927), total soluble solids (TSS) percentage was measured using hand refractometer, juice purity percentage was determined as a ratio between sucrose and TSS \% according to Carruther and Olfield (1961) and sugar weight plant ${ }^{-1}$ was calculated (root weight $X$ sucrose \%). Also, infested plant roots were examined for developmental stages after staining by lactic acid- fuchsin (Byrd et al., 1983) and recorded. Number of Meloidogyne javanica in soil was also determined by extracting through sieve and modified Baermann- pan technique (Goodey, 1957) and recorded. The nematode reproduction factor and reduction\% were calculated. Data analysis statically using the least significant differences (Steel and Torrie, 1987).

\section{Results}

Two organic acids (ascorbic and salicylic acids) and two amino acids (L-arginine and L-glutamic acids) solution applied as soil drench in three levels (1000, 2000 and 4000 ppm) were tested for their effectiveness against root-knot nematode, Meloidogyne javanica infecting sugarbeet plant. Their effects on sugarbeet yield and its components and quality parameters were determined.

\section{Effects of selected organic and amino acids on development and} reproduction of root-knot nematode, Meloidogyne javanica infecting sugarbeet

The effect of ascorbic, salicylic, L- arganine and L- glumatic acids on development and reproduction of $M$. javanica root-knot nematode are summarized in Table (1). The data indicate that the effect of the tested materials on reduction of $M$. javanica nematode parameters varied according to the chemical itself and concentration level used. All of treatments exhibited significant reduction in members of $J_{2}$ in soil pot ${ }^{-1}$, immature stages and mature females root $^{-1}$ system as well as final nematode population and reproduction factor compared to the check treatment. Remarkable differences in nematode suppression were noticeable among the tested concentration levels. Then, the reduction of nematode numbers and fecundity increased by increasing the concentration of each tested organic or amino acid. At a concentration level of 4000 ppm for all tested organic and amino acids, the reduction nematode population and fecundity were evident.

Among the tested materials, the ascorbic acid achieved a higher reduction in all nematode parameters at all concentration levels compared to the other tested 
materials and the check treatment. At the 4000 ppm concentration level, ascorbic acid yielded the highest reduction in all nematode parameters compared to the check treatment with $2498 \mathrm{~J}_{2}$ pot $^{-1}, 1663$ and 280 ind. root $^{-1}$ of immature stages and mature females, respectively. Salicylic acid achieved its highest results with $2730 \mathrm{~J}_{2}$ pot $^{-1}, 1653$ and 290 ind. root $^{-1}$ system of the immature stages and mature females, respectively. Inimical effects were also achieved by L-arginine acid followed by Lglutamic acid at their highest concentration level (4000 ppm) as shown Table (1).

The results presented in the same Table clearly revealed that the highest reduction in nematode final population, $74.6 \%$ was achieved when using the nematicide, Oxamyl at its highest concentration level. Ascorbic acid, salicylic acid and L-arginine acid followed by L-glutamic acid caused reduction in final nematode population with $71.6,68.0,53.6$ and $39.7 \%$, respectively, at their highest concentration levels.

Nematode reproduction factor was significantly decreased by acid solution treatments at all concentration levels compared to the check. The highest reduction in nematode reproduction factor was achieved using the highest solution levels. The lowest reproduction factor value of $M$. javanica (1.9 fold) was achieved with the nematicide, oxamyl even at its highest levels, followed by ascorbic, salicylic Larginine and L-glutamic acids at their highest levels with an average of 2.1, 2.3, 3.4 and 4.4 fold, respectively at their highest concentration levels.

In short, the plants received the nematicide, Oxamyl and organic compounds, ascorbic acid treatments at their highest concentration levels achieved the highest reduction $\%$ of $\mathrm{J}_{2}$ population in soil and final population number and lowest reproduction factor with values of $73.6,74.6 \%$ and 1.9 fold for Oxamyl, and 76.3, $71.6 \%$ and 2.1 fold for ascorbic acid, respectively

\section{Effects of selected organic and amino acids on growth and quality parameters of sugarbeet infecting by root-knot nematode, Meloidogyne javanica}

Data of sugarbeet growth and quality parameters as influenced by amino and organic acids are shown in Table (2 and 3). The results in Table (2) shows positive relationship among all the organic and amino acid treatments and both plant leaves and root as well as sugar yields. It was observed that all treatment of concentration levels caused significant increase in weights of leaves, root and sugar when compared to the check treatment.

In case of leaves weight, a significant increase was observed in leaves weight especially at all application concentration levels of all the tested compounds. The maximum increments as compared to check treatment were achieved when using amino or organic acids at their highest concentration levels. The greatest leaves weight (228.82 $\mathrm{g} \mathrm{plant}^{-1}$ ) as compared to the check treatment (156.28 g plant $^{-1}$ ) was achieved when using ascorbic acid at its highest level followed, by 
salicylic, L-arginine and finally L-glutamic acids at their highest levels with values of 226.07, 197.77 and 192.97 g, plant $^{-1}$, respectively.

Regarding the root weight, proportional effects were observed among the tested materials concentration levels and the root weight. A positive correlation between root weight and amino or organic acid concentration levels was evident. Ascorbic acid at a level of 4000 ppm yielded $717.93 \mathrm{~g} \mathrm{plant}^{-1}$ in root weight, while salicylic acid at the same level yielded $678.83 \mathrm{~g} \mathrm{plant}^{-1}$ followed by L-arginine and Lglutamic acids with values of 656.57 and $590.11 \mathrm{~g} \mathrm{plant}^{-1}$, respectively.

Concerning sugar yield, results indicate a positive correlation between sugar yield plant $^{-1}$ and amino or organic acid concentration level. The highest increases compared to the check treatment were achieved at the highest concentration level of each amino or organic acid. For instance, solution of ascorbic acid at the concentration level of $4000 \mathrm{ppm}$ yielded $137.77 \mathrm{~g} \mathrm{plant}^{-1}$ in sugar yield, while, solution of salicylic acid at the same concentration level yielded $127.69 \mathrm{~g} \mathrm{plant}^{-1}$ followed by L-arginine and L-glutamic acids with values of 118.18 and $104.87 \mathrm{~g}$ plant $^{-1}$, respectively.

Generally, Oxamyl as comparable treatment at level of $4 \mathrm{~g} \mathrm{pot}^{-1}$ yielded $265.14 \mathrm{~g} \mathrm{plant}^{-1}$ in leaves, $728.13 \mathrm{~g} \mathrm{plant}^{-1}$ in root and $136.31 \mathrm{~g} \mathrm{plant}^{-1}$ in sugar plant $^{-1}$.

The data on sugarbeet quality as influenced by amino or organic acid are shown in Table, (3). Generally, positive relations occurred between the compounds treatments, and quality parameters at all application. The greatest increases in sucrose, TSS and purity percentages were observed at the highest levels of all treatments compared to the check treatment. Based on sucrose percent, the most effective treatment was observed with ascorbic acid at maximal level, yielding a percent of $19.19 \%$. This was followed by salicylic, L-arginine and L-glutamic acids at their maximum levels with values of $18.81,18.0$, and $17.77 \%$, respectively. Furthermore, at the highest levels of tested organic and amino acids, TSS and purity\% were also increased compared to the check treatment. For instance, Ascorbic acid yielded 23.2 and $82.72 \%$ in TSS and purity\%, respectively followed by Salicylic, L-arginine and L-glutamine acids with values of 22.8, 22.05 and 22.0 in TSS, 82.50, 81.63, and 80.77in purity\%, respectively. While the comparable nematicide, Oxamyl achieved the highest increase even at the highest level with values of $18.72,22.06$ and $84.86 \%$, in sucrose, TSS and purity, respectively. Significant differences were detected among the compounds treatments. Generally, in comparing between the amino and organic acid compounds, the second compounds were more effective than the first ones.

Finally, the nematicide, Oxamyl and organic acid, ascorbic at their highest concentration levels showed the best results in improving root and sugar yield plant $^{-1}$ with values of (68.09 \& $\left.124.12 \%\right)$ and (65.73 \& 126.51\%), respectively. 
Table (1): Effect of selected organic and amino acids on the development and reproduction of root-knot nematode, Meloidogyne javanica infecting sugarbeet.

\begin{tabular}{|c|c|c|c|c|c|c|c|c|c|c|}
\hline \multirow[t]{2}{*}{ Treatments } & \multirow[t]{2}{*}{ Level } & \multicolumn{2}{|c|}{$\begin{array}{c}J_{2} \text { in soil } \\
\text { pot }^{-1}\end{array}$} & \multicolumn{3}{|c|}{ In root system } & \multicolumn{3}{|c|}{$\begin{array}{c}\text { Final } \\
\text { Population }\left(P_{\mathrm{f}}\right) \\
\end{array}$} & \multirow[t]{2}{*}{ RF } \\
\hline & & No. & $\mathbf{R} \%$ & $\begin{array}{c}\text { Immature } \\
\text { stages }\end{array}$ & $\begin{array}{c}\text { Mature } \\
\text { females }\end{array}$ & Total & $\mathbf{R} \%$ & No. & $\mathbf{R} \%$ & \\
\hline \multicolumn{11}{|l|}{ Organic acids } \\
\hline \multirow{3}{*}{$\begin{array}{l}\text { Ascorbic } \\
\text { (ppm) }\end{array}$} & 1000 & 5869 & 44.3 & 2311 & 410 & 2721 & 33.1 & 8590 & 41.2 & 4.3 \\
\hline & 2000 & 3678 & 65.1 & 1846 & 340 & 2186 & 46.3 & 5864 & 59.9 & 2.9 \\
\hline & 4000 & 2498 & 76.3 & 1363 & 280 & 1643 & 59.6 & 4141 & 71.6 & 2.1 \\
\hline Mean & & 4015 & 61.9 & 1940 & 343.3 & 2283.3 & 43.9 & 6298.3 & 56.9 & 3.2 \\
\hline \multirow{3}{*}{$\begin{array}{l}\text { Salicylic } \\
\text { (ppm) }\end{array}$} & 1000 & 6350 & 39.8 & 2803 & 386 & 3189 & 21.6 & 9539 & 34.7 & 4.8 \\
\hline & 2000 & 4005 & 62.0 & 2060 & 351 & 2411 & 40.7 & 6416 & 56.1 & 3.2 \\
\hline & 4000 & 2730 & 74.1 & 1653 & 290 & 1943 & 52.2 & 4673 & 68.0 & 23 \\
\hline Mean & & 4361.7 & 58.6 & 2172 & 342.3 & 2514.3 & 38.2 & 6876 & 52.9 & 3.4 \\
\hline \multicolumn{11}{|l|}{ Amino acids } \\
\hline \multirow{3}{*}{$\begin{array}{l}\text { L-arginine } \\
\text { (ppm) }\end{array}$} & 1000 & 7540 & 28.5 & 2926 & 300 & 3226 & 20.7 & 10766 & 26.3 & 5.4 \\
\hline & 2000 & 6237 & 40.8 & 2283 & 391 & 2674 & 34.3 & 8911 & 39.0 & 4.5 \\
\hline & 4000 & 4209 & 60.1 & 2273 & 301 & 2574 & 36.7 & 6778 & 53.6 & 3.4 \\
\hline Mean & & 5993.7 & 43.1 & 2494 & 330.7 & 2824.7 & 30.6 & 8818.3 & 39.6 & 4.4 \\
\hline \multirow{3}{*}{$\begin{array}{l}\text { L-glutamic } \\
\text { (ppm) }\end{array}$} & 1000 & 8241 & 21.8 & 3061 & 501 & 3562 & 12.4 & 11803 & 19.2 & 5.9 \\
\hline & 2000 & 7820 & 25.8 & 2370 & 441 & 2811 & 30.9 & 10631 & 27.2 & 5.3 \\
\hline & 4000 & 6142 & 41.7 & 2249 & 411 & 2660 & 34.6 & 8802 & 39.7 & 4.4 \\
\hline Mean & & 7401.0 & 29.8 & 2560 & 451 & 3011.0 & 26.0 & 10412 & 28.7 & 5.2 \\
\hline \multicolumn{11}{|l|}{ Nematicide } \\
\hline \multirow{3}{*}{$\begin{array}{l}\text { Oxamyl } \\
\left(\text { g pot }^{-1}\right)\end{array}$} & 1 & 5864 & 44.4 & 1508 & 300 & 1808 & 55.6 & 7672 & 47.5 & 3.8 \\
\hline & 2 & 4328 & 58.9 & 1236 & 252 & 1488 & 63.4 & 5816 & 60.2 & 2.9 \\
\hline & 4 & 2784 & 73.6 & 760 & 164 & 924 & 77.3 & 3708 & 74.6 & 1.9 \\
\hline Mean & & 4325.3 & 59.0 & 1168 & 238.7 & 1406.7 & 65.4 & 5732 & 60.8 & 2.9 \\
\hline Check & & 10540 & 0.00 & 3320 & 0.00 & 4068 & 0.00 & 14608 & 0.00 & 7.3 \\
\hline $\begin{array}{l}\mathrm{LSD}_{0.05} \\
\text { between } \\
\text { treatment }(\mathrm{A})\end{array}$ & & 139.5 & & 98.1 & 73.7 & 121.3 & & 197.4 & & 0.1 \\
\hline $\begin{array}{l}\text { between } \\
\text { levels (B) }\end{array}$ & & 98.7 & & 69.4 & 52.1 & 85.8 & & 139.6 & & 0.07 \\
\hline$A \times B$ & & 170.9 & & 120.2 & 90.3 & 148.6 & & 241.8 & & 0.1 \\
\hline
\end{tabular}


Table (2): Effect of selected organic and amino acids on leaves, root and sugar weights of sugarbeet infecting by root- knot nematode, Meloidogyne javanica.

\begin{tabular}{|c|c|c|c|c|c|c|c|}
\hline \multirow{2}{*}{ Treatments } & \multirow{2}{*}{ Level } & \multicolumn{2}{|c|}{ Leaves plant $^{-1}$} & \multicolumn{2}{|c|}{ Root plant $^{-1}$} & \multicolumn{2}{|c|}{ Sugar plant $^{-1}$} \\
\hline & & g. & Inc. \% & g. & Inc. $\%$ & g. & Inc. $\%$ \\
\hline \multicolumn{8}{|l|}{ Organic acids } \\
\hline \multirow{3}{*}{$\begin{array}{l}\text { Ascorbic } \\
\text { (ppm) }\end{array}$} & 1000 & 202.23 & 29.40 & 600.11 & 38.54 & 102.61 & 68.70 \\
\hline & 2000 & 215.33 & 37.78 & 661.01 & 52.59 & 121.81 & 100.28 \\
\hline & 4000 & 228.82 & 46.42 & 717.93 & 65.73 & 137.77 & 126.51 \\
\hline \multirow[t]{2}{*}{ Mean } & & 215.46 & 37.87 & 659.68 & 52.29 & 120.73 & 98.50 \\
\hline & 1000 & 198.19 & 26.82 & 579.81 & 33.85 & 98.57 & 62.07 \\
\hline \multirow{2}{*}{$\begin{array}{l}\text { Salicylic } \\
\text { (ppm) }\end{array}$} & 2000 & 213.93 & 36.89 & 634.07 & 46.38 & 115.65 & 90.15 \\
\hline & 4000 & 226.07 & 44.66 & 678.83 & 56.71 & 127.69 & 109.95 \\
\hline Mean & & 212.73 & 36.12 & 630.90 & 45.64 & 113.97 & 87.39 \\
\hline \multicolumn{8}{|l|}{ Amino acids } \\
\hline & 1000 & 171.23 & 9.57 & 545.69 & 25.97 & 89.22 & 46.70 \\
\hline \multirow{2}{*}{$\begin{array}{l}\text { L-arginine } \\
\text { (ppm) }\end{array}$} & 2000 & 184.06 & 17.78 & 564.26 & 30.26 & 98.29 & 61.61 \\
\hline & 4000 & 197.77 & 26.55 & 656.57 & 51.57 & 118.18 & 94.31 \\
\hline \multirow[t]{2}{*}{ Mean } & & 184.35 & 17.97 & 588.84 & 35.93 & 101.90 & 67.54 \\
\hline & 1000 & 164.64 & 5.35 & 509.20 & 17.55 & 84.18 & 38.40 \\
\hline \multirow{2}{*}{$\begin{array}{l}\text { L- glutamic } \\
\text { (ppm) }\end{array}$} & 2000 & 180.76 & 15.66 & 544.13 & 25.61 & 92.52 & 52.12 \\
\hline & 4000 & 192.97 & 23.48 & 590.11 & 36.23 & 104.87 & 72.43 \\
\hline Mean & & 179.46 & 14.83 & 547.81 & 26.46 & 93.86 & 54.32 \\
\hline \multicolumn{8}{|l|}{ Nematicide } \\
\hline & 1 & 177.27 & 13.43 & 508.76 & 17.45 & 84.42 & 38.80 \\
\hline \multirow{2}{*}{$\begin{array}{l}\text { Oxamyl } \\
\left(\text { g pot }^{-1}\right)\end{array}$} & 2 & 214.41 & 37.20 & 555.54 & 28.25 & 96.50 & 58.67 \\
\hline & 4 & 265.14 & 69.66 & 728.13 & 68.09 & 136.31 & 124.12 \\
\hline Mean & & 218.94 & 40.09 & 597.48 & 37.93 & 105.74 & 73.86 \\
\hline Check & & 156.28 & 0.00 & 433.18 & 0.00 & 60.82 & 0.00 \\
\hline Healthy & & 252.69 & 61.69 & 746.77 & 72.39 & 136.74 & 124.82 \\
\hline $\begin{array}{l}\mathrm{LSD}_{0.05} \text { between } \\
\text { treatments }(\mathrm{A})\end{array}$ & & 4.71 & & 12.67 & & 2.39 & \\
\hline $\begin{array}{c}\mathrm{LSD}_{0.05} \text { between } \\
\text { levels }(\mathrm{B})\end{array}$ & & 3.08 & & 8.29 & & 1.56 & \\
\hline$A \times B$ & & 5.77 & & 15.52 & & 2.92 & \\
\hline
\end{tabular}

Inc. = Increase 
Table (3): Effect of selected organic and amino acids on quality parameters of sugarbeet infecting by root-knot nematode, Meloidogyne javanica.

\begin{tabular}{|c|c|c|c|c|c|c|c|}
\hline \multirow{2}{*}{ Treatments } & \multirow{2}{*}{ Level } & \multicolumn{2}{|c|}{ Sucrose } & \multicolumn{2}{|c|}{ TSS } & \multicolumn{2}{|c|}{ Purity } \\
\hline & & $\%$ & Inc. \% & $\%$ & Inc. \% & $\%$ & Inc. \% \\
\hline \multicolumn{8}{|l|}{ Organic acids } \\
\hline \multirow{3}{*}{$\begin{array}{l}\text { Ascorbic } \\
\text { (ppm) }\end{array}$} & 1000 & 17.10 & 21.79 & 21.09 & 16.39 & 81.08 & 4.64 \\
\hline & 2000 & 18.43 & 31.27 & 22.24 & 22.74 & 82.87 & 6.95 \\
\hline & 4000 & 19.19 & 36.68 & 23.20 & 28.04 & 82.72 & 6.76 \\
\hline \multirow[t]{2}{*}{ Mean } & & 18.24 & 29.91 & 22.18 & 22.39 & 82.22 & 6.12 \\
\hline & 1000 & 17.00 & 21.08 & 21.10 & 16.45 & 80.58 & 3.99 \\
\hline \multirow{2}{*}{$\begin{array}{l}\text { Salicylic } \\
\text { (ppm) }\end{array}$} & 2000 & 18.24 & 29.91 & 22.49 & 24.12 & 81.10 & 4.67 \\
\hline & 4000 & 18.81 & 33.97 & 22.80 & 27.48 & 82.5 & 5.09 \\
\hline Mean & & 18.07 & 28.32 & 22.23 & 22.68 & 81.04 & 4.58 \\
\hline \multicolumn{8}{|l|}{ Amino acids } \\
\hline & 1000 & 16.35 & 16.45 & 20.52 & 13.25 & 79.68 & 2.83 \\
\hline \multirow{2}{*}{$\begin{array}{l}\text { L-arginine } \\
\text { (ppm) }\end{array}$} & 2000 & 17.42 & 24.07 & 21.85 & 20.58 & 79.73 & 2.90 \\
\hline & 4000 & 18.00 & 28.21 & 22.05 & 21.69 & 81.63 & 5.35 \\
\hline \multirow[t]{2}{*}{ Mean } & & 17.26 & 22.91 & 21.47 & 18.51 & 80.35 & 3.69 \\
\hline & 1000 & 16.53 & 17.74 & 20.52 & 13.25 & 80.56 & 3.96 \\
\hline \multirow{2}{*}{$\begin{array}{l}\text { L- glutamic } \\
\text { (ppm) }\end{array}$} & 2000 & 17.00 & 21.08 & 21.00 & 15.89 & 80.95 & 4.47 \\
\hline & 4000 & 17.77 & 26.57 & 22.00 & 21.41 & 80.77 & 4.24 \\
\hline Mean & & 17.10 & 21.79 & 21.17 & 16.85 & 80.76 & 4.23 \\
\hline \multicolumn{8}{|l|}{ Nematicide } \\
\hline & 1 & 16.59 & 18.16 & 19.81 & 9.33 & 83.74 & 8.08 \\
\hline \multirow{2}{*}{$\begin{array}{l}\text { Oxamyl } \\
\left(\text { g pot }^{-1}\right)\end{array}$} & 2 & 17.37 & 23.72 & 20.47 & 12.97 & 84.86 & 9.51 \\
\hline & 4 & 18.72 & 33.33 & 22.06 & 21.74 & 84.86 & 9.52 \\
\hline Mean & & 17.56 & 25.07 & 20.78 & 14.68 & 84.49 & 9.04 \\
\hline Check & & 14.04 & 0.00 & 18.12 & 0.00 & 77.48 & 0.00 \\
\hline Healthy & & 18.31 & 30.41 & 22.00 & 21.41 & 83.23 & 7.42 \\
\hline $\begin{array}{l}\mathrm{LSD}_{0.05} \text { between } \\
\text { treatments }(\mathrm{A})\end{array}$ & & 0.111 & & 0.167 & & 0.881 & \\
\hline LSD $_{0.05}$ between levels (B) & & 0.073 & & 0.109 & & 0.577 & \\
\hline$A \times B$ & & 0.136 & & 0.204 & & 1.079 & \\
\hline
\end{tabular}

Inc. = Increase 


\section{Discussion}

With respect to the tested organic and amino acids under greenhouse conditions viz. ascorbic, salicylic, L-arganine and L-glutamic acids, they had a negative effect on the development and reproduction of Meloidogyne javanica on sugarbeet var. Helios. This was indicated by the lower population density of $M$. javanica juveniles in soil and root system, and other developmental stages as well as reproduction factor. This coincided with improvement in plant growth and quality of the treated pots and an increase in leaves, roots and sugar weights. These findings are in agreement with those of El-Sayed (1986); Al-Sayed and Thomason (1988); Osman (1993); Hassan (1999) and Nandi et al., (2002) who found that solutions of some organic and/or amino acids suppressed the numbers of second stage juveniles, females, egg-masses, root galls of $M$. incognita and $M$. javanica, root-knot nematode on other hosts.

Arrigoni et al., (1979) suggested that ascorbic acid plays a key role in defense mechanism of plants to pathogens such as root-knot nematodes. The amount of ascorbic acid in susceptible tomato cultivars was reported to be lower than in resistance cultivars. A decrease in plant ascorbic acid content can reduce the resistance of tomato plants to nematode infection (Mellilo et al. 1983). ElSayed (1989) reported that ascorbic acid was more effective than L-arginine in reducing nematode, $M$. incognita on tomato plant. However, Osman (1993) found that L-arginine acid reduced nematode population and affected maturity and fecundity of $M$. javanica females in tomato roots.

Also, the data revealed that salicylic acid was found to reduce the number of nematode second stage juveniles, other developmental stages and consequently lowering reproduction factor of $M$. javanica. These results are in agreement with those obtained by Hassan (1999) and Nandi et al. (2002) who reported that the application of salicylic acid significantly suppressed population of $M$. incognita and M. javanica on cowpea and cucumber plants. Salicylic acid is known to play a critical signaling role in the activation of plant defense responses after pathogen attack (Klessig et al., 2000). The mode of action of salicylic acid i.e. enhance defense mechanisms in the plant tissue (Canet et al., 2010) and increased resistance against Meloidogyne spp. (Siddique and Shaukat, 2004 \& 2005 and Sirohi and Rohatgi, 2006).

In short, in comparing between the effects of nematicide, Oxamyl and ascorbic acid on development and reproduction factors as well as sugarbeet productivity (Tables, 1, 2 and 3), the results ${ }^{v}$ suggest that using of ascorbic acid (at $4000 \mathrm{ppm}$ rate) could be recommended as instead of chemical nematicides to be a main nematode management approach, whether using as part of an integrated management program or as sole control component. 


\section{References}

Al Sayed, A. A. (1992). Effect of ascorbic acid and L-arginine on controlling Meloidogyne incognita as influenced by soil temperature. Annals of Agricultural Science, Moshtohor 30(3): 1549-1558.

Al-Sayed, A.A. and Thomason, I.J. (1988). Meloidogyne incognita and tomato response to thiamine, ascorbic, L-arginin and L-glutamic acid. Journal of Nematology, 20(3): 451-456.

Al-Sayed, A.A. (1986). The role of ascorbic acid and glutamic acid in controlling the root-knot nematode, Meloiaogyne javanica. Egypt Journal of Phytopathology, 18 (2): 143-148.

Al-Sayed, A.A. (1989). Effect of ascorbic acid and L-arginine on controlling Meloidogyne incognita as influenced by soil temperature. Egypt Journal of Phytopathology, 21: 179-184.

Al-Sayed, A.A. (1990). The inhibitory effect of ascorbic acid on Meloidogyne incognita infecting tomato. Annals of Agric. Sci. Moshtohor, 28(3): 17371740.

Al-Sayed, A.A. (1991). Rotylenchulus reniformis and soybean response to ascorbic acid. Annals of agricultural science, Moshtohor. Vol. 29 (3): 1227-1232.

Al-Sayed, A.A. and Montasser, S.A. (1986). The role of ascorbic and glutamic acids in controlling the root knot nematode Meloidogyne javanica. Egypt. J. Phytopathol. 18 (2): 143-148.

Arrigoni, O.; Zacheo, R.; Arrigoni-liso, T.; Belevezacheo and Lamberti, F. (1979). Relationship between ascorbic acid and the resistance in tomato plants to Meloidogyne incognita. Journal of Phytopathology, 69: 579-581.

Byrd, D.W.; Kirkpatrick, T. and Barker, K.R. (1983). An improved technique for clearing and staining plant tissue for detection of nematodes. Journal of Nematology 14:142-143.

Canet, Juan V.; Dobón, A.; Ibáñez, F; Perales, L. and Tornero, P. (2010). Resistance and biomass in Arabidopsis: a new model for Salicylic Acid perception. Plant Biotechnology Journal 8(2): 126 - 141.

Carruthers, A. and Oldfied, J.F. T. (1961). Methods for assessment of beet quality. International Sugar Journal, 63: 137-139.

Gohar, I.M.A. (2003). The relationships between plant parasitic nematodes of sugarbeet and other soil fauna. Ph.D Thesis, Fac. Of Agric. Moshtohor, Zagazig Univ., Egypt. $221 \mathrm{Pp}$. 
Gohar, I.M.A. and Maareg, M. F. (2005). Relationship Between Crop Losses and Initial Population Densities of Root-knot Nematode, Meloidogyne incognita in soil of Sugarbeet Grown in West Nubariya Region. Egypt. J. Agric. Res., 83 (2): $1315-1328$.

Goodey, J.B. (1957). Laboratory methods for work with plant and soil nematodes. Tech.Bull.No.2 Min. Agric. Fish Ed.London,pp.47.

Hassan, H.M. (1999). Effect of some antioxidants on the response of cucumber to Meloiaogyne javanica infection and the activity of the plant peroxidase. Egypt. J. Agronematology 3(1/2): 139-148.

Klessig, D.F.; Durner, R. Noad; Navarre, D.A.; Wendehenne, D.; Kumar, D.; Zhou, J.M.;Shah, J.;Zhang, S.; Kachroo, P.; Tarifa, Y.; Pontier, D.; Lam, E. and silva, H. (2000). Nitric oxide and salicylic acid signaling in plant defence. Proc. Natl. Acad. Sci. USA, 16: 8849-8855.

Le-Docte, A. (1927). Commercial determination of sugar in the beet root using the Sacher Le-Docte process. Inernational Sugar Journal, 29:448-492.

Maareg M. F and Hassanein, M.A. (1999). Survey and ecological studies on plant parasitic nematodes in the West of Nubaryia: In. The effects of nematode on sugarbeet at Al-Bostan region. Project funded from National Council of Sugar Crops (NCSC). 51 pp.

Maareg M. F; Gohar, I. M.A. and Abdel Aal, A.M. (2005). Susceptibility of twenty one sugarbeet varieties to the root-knot nematode, Meloidogyne incognita at West Nubariya District.. Egypt. J. Agric. Res., 83 (2): 789- 801.

Melillo, M.T.; Zacheo, G. and beleve-Zacheo T. (1983). Effect of ascorbic acid on gall formation in tomatoes susceptible to Meloidogyne incognita. nematologica Mediterranea, 11:157-167.

Nandi, B.; Sukual, N.C.; Banerjee, N.; Sengupta, S.; Das, P. and Babu, P.S. (2002). Salicylic acid and enhances resistance in cowpea against Meloidogyne incognita. Phytopathology Medit., 41:39-44.

Osman, G.Y. (1993). Effect of amino acids and ascorbic acid on Meloiaogyne javanica chitw. (Tylenchidae, Nematode). Amgeiger für Schädlingskunde. 66(7):140-142.

Siddiqui, I.A. and Shaukat, S.S. (2004). Systemic resistance in tomato induced by biocontrol against the root-knot nematode, Meloidogyne javanica is independent of salicylic acid production. J. Phytopathology. 152:48-54.

Siddiqui, I.A. and Shaukat, S.S. (2005). Pseudomonas aeruginosa- mediated induction of systemic resistance in tomato against root-knot nematode. Plant Pathology Journal 4(1): 21-25. 
Sirohi, A.P. and Rohatgi, D. (2006). Salicylic acid induced resistance against Meloidogyne incognita in tomato. Annals of plant protection science. 14, Issue: 1 print ISSN:0971-3573

Sirohi, A.P.; Rohatgi, D. and Chaudhary, D. (2008). root-knot nematode, Meloidogyne incognita and salicylic acid induce production of PR-proteins in tomato. Indian Journal of Nematology, 38, Issue:1 print ISSN: 0303.

Southey, J.F. (1970). Laboratory methods fpr work with plant and soil nematode. Minist. Agric., Fish \& Food Tech. Bull. 2 Her Majesty's Stationary Office, London, 148p.

Steel, R.G.D. and Torrie, J.H. (1981). Principles and procedures of statistics, a biometrical approach. 2nd ed. by Mc Graw-Hill International Book Company, Singapore, pp. 633. 


\section{الملخص العربي}

إستراتيجية إدارة مكافحة نيماتودا تعقد الجذور على بنجر السكر بوسائل صديقة للبيئة 2 - استخدام الأحماض الأمينية والعضوية

محمد فتحي معارج*، عبد المنعم ياسين الجندي **، إبراهيم محمد عبد جوهر*، وكمال محمد عجمي * قسم الأمراض والآفات وقسم المعاملات الزراعية بمعهد بحوث المحاصيل السكرية، مركز البحوث الزراعية، و ج ج ا I الجيزة،

$$
\text { مصر. *قم الحيوان والنيماتولوجيا الزراعية، كلية الزراعة، جامعة القاهرة، الجيزة، مصر. }
$$

نظرًا لافتقار المقاومة في معظم أصناف بنجر السكر لنيماتودا تعقد الجذور والتي تسبب أضرارًا اقتصادية وخسائر فادحة في محصول الجذر والسكر الناتج، ولما كانت المبيدات النيماتودية عالية التكاليف من الناحية الاقتصادية وذات تأثير ضار على البيئة وصحة الإنسان والحيوان فإن الاتجاهات الحديثة هو البحث عن وسائل

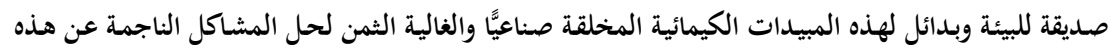

ومن هذه الوسائل استخدام بعض الأحماض الأمينية والعضوية ولذا تم تقييم فاعلية أربعة أحماض، اثنان

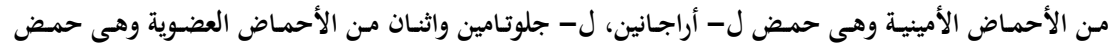
الأسكوربيك، وحمض السالسليك ضسد نيماتودا تعقد الجذذور النوع مليدوجين جافانيكا التي تصيب محصول بنجر السكر

ولقد استخدمت هذه المـواد بثثلاث تركيزات: . . . . 1 . . . . . . . . . . . ع جـزء في المليون مضـافة للتربة مقارنة بالمبيد الكيميائي أوكسامايل وقد وجد أن هذه المركبات تختلف من حيث تأثيرها على النيماتودا والمحصول من حيث نوع المركب والتركيز المستخدم.

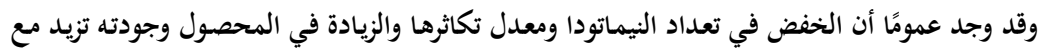
زيادة التركيز المستخدم لكل مركب، وأوضحت الدراسة أن كل المركبات المستخدمة أحدثت خفضًا معنويًّا في أعداد الأطوار المختلفة للنيماتودا في التربة والجذر والتعداد النهائي ومعدل تكاثرها، كما أحدثثت زيادة معنورية في الصفات المحصولية والجودة مقارنة بمعاملة الكنترول. كما وجـد أن حمض الأسكوربيك أكثر المركبات فاعلية في خفض تعداد الأطوار المختلفة للنيماتودا وتعدادها النهائي ومعدل تكاثرها يليه حمض الهض السالسليك ثم

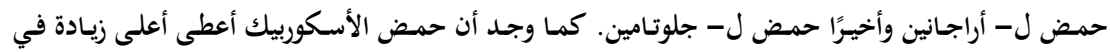
محصول الأوراق والجذور والسكر وصفات الجودة (نسب السكر والمواد الصلبة الذائبة الكلية والنقاوة) مقارنة بالمركبات المختبرة الأخرى. وفى مقارنة بين فاعلية حمض الأسكوربيك وفاعلية المبيد النيماتودى أوكسامايل في التأثير على تطور النيماتودا ومعدل تكاثرها وكذلك الثأثير على إنتاجية محصول بنجر السكر وجد أن حمض الأسكوربيك خفض

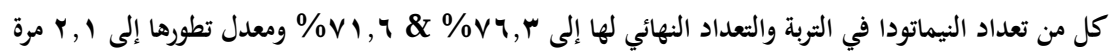

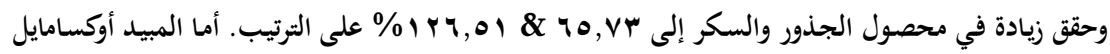

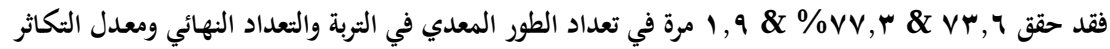

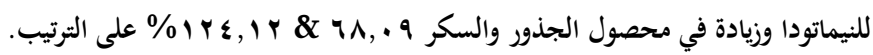
ونظرًا للمشاكل المصاحبة لتطبيق المبيدات النيماتودية أدى إلى التوجه إلى البحث عن وسئ وسائل أو مركبات

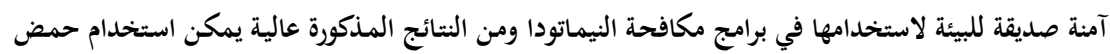


الأسكوربيك بتركيز . . ؛ جزء في المليون بديلاً عن المبيدات الكيميائية المختلفة أو استخدامه في برامج

المكافحة المتكاملة للآفات النيماتودية. 